\title{
Buddhist Approach To The Psycho-Social Issues Relating To The Families Of Missing Persons In The Civil War In Sri Lanka (FROM 1983 - 2009)
}

\author{
Janaka Mudalige
}

Prof. Phramahā Somboon Vuḍ̣hikaro, Dr.

Prof. Upali M. Sedere Dr.

Prof. Daya Edirisinghe Dr.

Prof. Iromi Ariyaratne Dr.

\author{
Mr. M. J. M. Mudalige
}

\begin{abstract}
The title of the Dissertation is "Buddhist Approach to the Psycho-social Issues Relating to the Families of Missing Persons in the Civil War in Sri Lanka (from 1983 _ 2009)" Researcher attempted weather Buddhist approach could help in minimization or eradication of psychosocial issues of the families of missing persons within the above scope. The loved ones of a missing person due to whatever the reason behind it live in constant severe mental and physical pain with lot of suffering. The complete loss or absence of hope, often waiting for years for good news creates the agony worst. The objective of the research is to find out existing Psycho-Social Issues in a mixture of quantitative \& qualitative research, aiming at the recommendations on a global perspective. Research question was finding out what happened to the missing people which has become a top priority in the world while families are living with uncertainty and severe mental agony and objectives of the research were to ascertain the magnitude of the humans suffering due to the loss of their loved one/s. Methodology of the research was framed on the basis of Mix of Qualitative and Quantitative data \& information research findings were developed based on the analysis of data and testing of hypothesis. Buddhist approach to the Psycho-social issues were found significantly important in the study. Researcher established the actual gap between the facts and figures based on 18891 total complaints received during the period of the mandate of PCICMP vs the total complaints announced at the discussions of United Nations in Geneva 23586. The importance of expediting the balance complaints and grievances were found. The lessons learnt from the Buddhist approach is well proved in conflict resolution in terms of Justice, Accountability of the Government, the process of Reconciliation, the Compensation, and Establishment of all possible ways \& means in order to avoid future occurrences were concluded.
\end{abstract}




\section{Location of Sri Lanka}

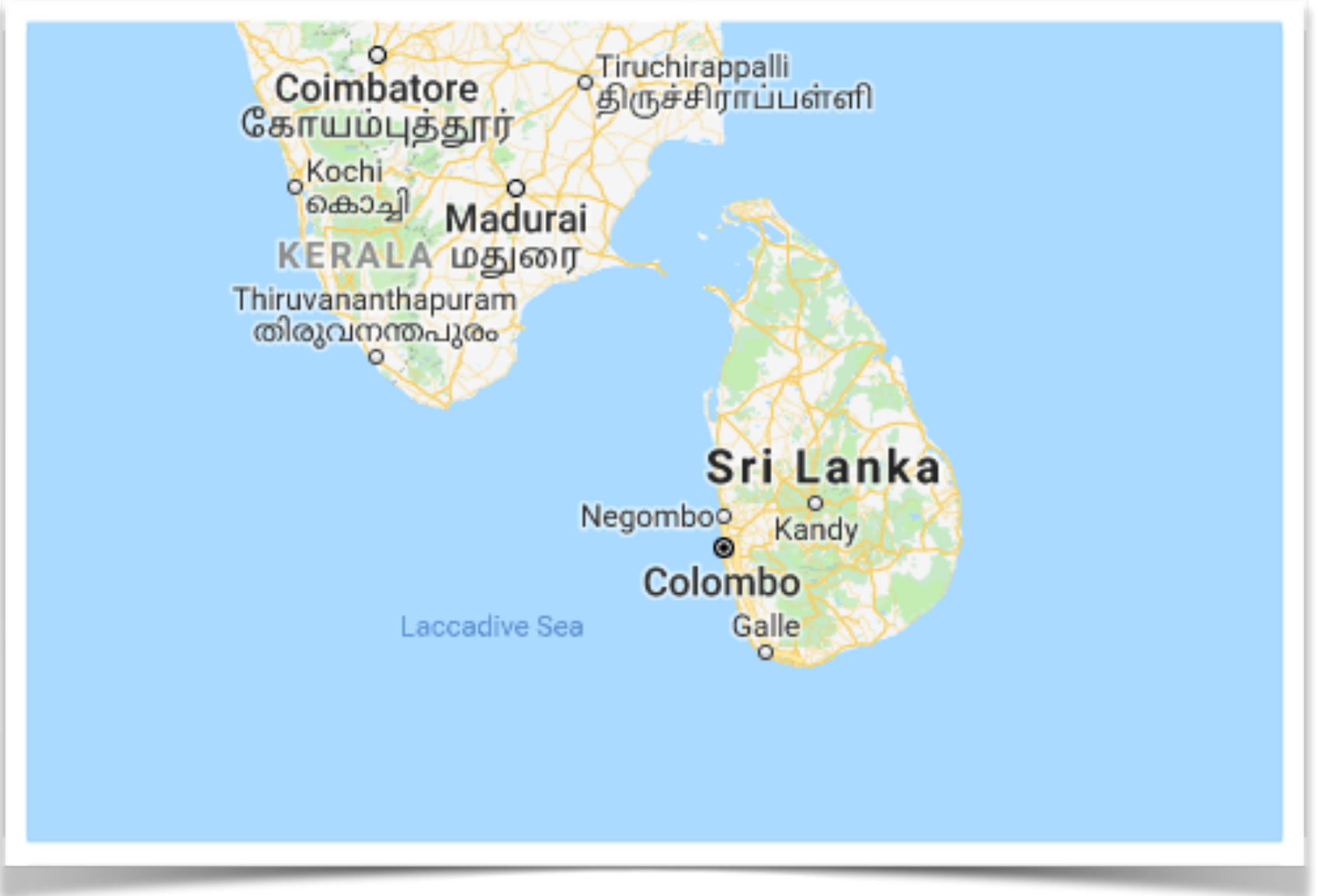

\section{CHAPTER I \\ INTRODUCTION}

Sri Lanka was formerly known as Ceylon, Serendib and Taprobane which locates near South East India. Maritime borders goes at the Northwest of India and Maldives in the south west. History spans more than 3000 years far back and the prehistoric human settlements are backed by the evidence more than 125,000 years. Original teachings of Buddhism still flourish in terms of Theravāda Buddhism.

Many locations available for attract for tourists such as memorable combination of beautiful sceneries, beautiful beaches, unmatched cultural heritage and many other unique experiences. Within $65610 \mathrm{Sq} \mathrm{Km}$ land area there are 8 sites recognized by UNESCO as World Heritage. Outer perimeter of the beach counts $1330 \mathrm{kms}$ of coastline where 15 national parks which shows an abundance of wildlife. Nearly 500000 hectares of lush forests and 250 hectares of botanical gardens, 350 waterfalls, 25,000 bodies of water also adds value to the Island.

Official name is Democratic Socialist Republic of Sri Lanka, Latitude is $5^{\circ} 55$ to $9{ }^{\circ} 50$ north, and longitude is $79^{\circ} 42$ to $81^{\circ} 52$ from $650 \mathrm{~km}$ north of the equator. Dimensions are $430 \mathrm{~km}$ from north to south, $225 \mathrm{~km}$ from east to west. Independence was received on February 4, 1948, administrative capital located in Sri Jayewardenepura while commercial capital located in Colombo. Climate is typically tropical, with a northeast monsoon from December to march where accidental weather in the north and east on June to October and occasional bad weather in the south and west. The highest mountain is Pidurutalagala which is 2,524 meters and the highest waterfall is Bambarakanda which is 263 meters. National flower is blue water lily (Nymphaea stellata). National parks and nature reserve are more than 8,000 sq.km where the population goes more than 21128773 last 2015 census in the country. 
Rate of growth of the population is $1.3 \%$ and density of population recorded as 309 people per square kilometer. Expected life at birth is 74 for women and 64 for men. Literacy Rate goes for Females 87.9 and Male counts 92.5. Multi ethnic groups are recorded such as Sinhalese 73.8\%, Sri Lanka Moors 7.2\%, Tamil 4.6\% Indian, Sri Lanka Tamil 3.9\%, other 0.5\%, unspecified 10\% (2001 census). Languages are Sinhalese (official and national) 74\%, Tamil (national language) $18 \%$, others $8 \%$ note English (a liaison language generally) is used in government and is competent with about $10 \%$ of the population. Religions are Buddhist $69.1 \%$, Muslim 7.6\%, Hindu 7.1\%, Christian 6.2\%, Unspecified 10\% according to Census in 2001. Time zone is five and a half hours before GMT. International numbering comments by +94 . The supply of electricity is 230 - 240 volts, 50 AC cycles. The most dynamic sectors in economy in Sri Lanka are agri food, textiles and clothing, food and beverages, port construction, telecommunications, insurance and banking. In 2006, accounted exports for textiles and clothing reached more than $60 \%$. About 800,000 Sri Lankans work abroad $90 \%$ of them in the Middle East. They send home more than $\$ 1$ billion a year. In terms of workforce $4.3 \%$ of the active population is employed in agriculture, $25.3 \%$ in industry and $40.4 \%$ in service sector. $40.4 \%$ (June 30 , is 2006.) Products on agriculture are Rice, sugarcane, cereals, legumes, oilseeds, spices, tea, rubber, coconut, milk, eggs, beef fish etc. Industries goes on processing of rubber, tea, coconuts, tobacco and other agricultural products, telecommunications, insurance, banking, clothing, textiles, cement, petroleum refining. Main exports streams are on textiles, clothing, tea, spices, diamonds, emeralds, coconut based products, rubber production, and fish while imports are on some of the textiles, mineral products, petroleum, food, machinery and transport equipment. Major partners in import are India 19.6\%, China 10.5\%, Singapore 8.8\%, Iran 5.7\%, Malaysia 5.1\%, Hong Kong 4.2\%, Japan 4.1\% based on the census in 2006.

\section{BACKGROUND OF MISSING PERSONS}

When compared with the conflicts taken place in the world such as Croatia, Bosnia Herzegovina and Kosovo considerable number of families have submitted the tracking and tracing applications approximately more than 34,000 for organizations of humanity. The primary objective was the aim to find out clue on what happened to their loved ones or how to recover their remains if they have died irrespective of the reason of the death. Therefore it has become a necessity in order to formulate proper strategies covering holistic approach assuring the assistance to the families of the Missing. They are for Sri Lanka is not the only country facing this type of challenge after eradicating 30 years civil war at on soils. Many other Nations tried to offer solutions while some of them offered arms and ammunitions to the terrorists on promotion of their business while the Geneva conventions were in force.

Most of the International guidelines were in absence in many occasions including in the case of Missing of people. As the legitimate authority of the country the responsibility of the Government bares the full responsibility in maintaining law and order in the country.

While maintaining the dignity of the missing persons and their members of the families always face a huge struggle within the loss of absence maybe on top of the mental agony and economical hardships. In Sri Lankan culture the families of missing persons deserve and receive most of the support from their neighbouring communities as well as from the organizations connected in relief. Most of the persons were recorded due to the armed conflict taken place in the country as the conflicts were taken place due to the unresolved issues over the period of time. The main reason was the issues for not properly attended by the legitimate government which were elected hundred percent based on the democratic paradigms. 
Even though the magnitude of the problem remains at a higher level and a broader perspective to be established still the problem remains unchanged due to many parameters. Researcher aims at developing a proper matrix in order to understand the reality at the grassroot level by analysing the primary and secondary sources in a scientific model. Individuals, groups, associations of various forms, Governmental actors, non Governmental organizations (NGOs), International non Governmental organizations, other delegates, psychologists, psychiatrists, lawyers and many other professionals from various subject domains are still active on the exercise in budding the comprehensive framework of support and Justice.

In the case of forced disappearance the subject matter is very much serious as the legitimate Government is responsible for everyone's life while Sri Lanka is a member of United Nations. Therefore adhering International convention for the protection of civilian life as well as the environment is compulsory by law.

In the case of forced disappearance the general public means the terms such as arrest, detention, abduction, etc. Sri Lankan civil war began on 23 July 1983 and the escalation was on and due to various reasons between the governments by the Liberation Tigers of Tamil Eelam (LTTE) who are widely known as Tamil Tigers because of the emblem of them was a tiger. Mainly they were interested in north and east of the Island. Number of repercussions faced by the present Governments irrespective the political parties such as the burden of loss of lives, casualties, aftermath consequences, economic costs, Strategies and political solutions, together with the procedures for implementation of the recommendations of Lessons Learnt and Reconciliation Commission, International criticism in many forums has a huge influence on inter governmental relations on humanitarian impact, Issues of resettlement of Detainees, alleged war crimes, clearing of land mines, facing of local \& international protests. All above factors are highly influential as the impacts or directly proportional on the road map of the accelerated development plan in the country.

This research efforts goes in order to establish a rationale in order to find out the actual parameters which are influential at the grassroot level by using a mixture of qualitative and quantitative method of research and find out the relevance of the facts taught in Buddhist teachings. Researcher believes a similar type of research is not been carried out during the time of the war as well as after termination of the war to date.

The research findings may be helpful to the Stakeholders before they make strategic decisions as proper research methodologies have been incorporated under the directives of senior academics in a methodical way. Conclusion and suggestions were developed based on the number of analysis done based on the data sets.

Finding best possible solutions for the families of the missing persons should not be emotionally biased but the suffering and the mental agony also calculated by using qualitative data which reflects on the quantitative parameters in another way. For example when a boy who went on missing at the age of 15 where is mother and father maybe in the age of 35 and 45. After 10 years if the boy was not missing he will be at the age of 25 and both parents have reached the age groups in 45 and 55. Due to the psychosocial effects which are highly on qualitative and the parameters influencing their health during the last 10 years may be reflected is quantitative research such as the blood sugar level or the pressure levels of the human body. In the structured interviews carried out in the north and east provinces these parameters are widely exposed and the researcher has created the eye opening for future research while he has done his research work within his scope. 
Suffering and living with mental agony with miserable life due to loss of their loved ones who went missing during the period of civil war from 23 July 1983 to 18th May 2009 which is 25 years 9 months 3 weeks and 4 days. Until such time the expected long term solutions the families of missing persons really need the economical support, then the psycho social support together with proper counselling while recognising their grievances and improving their livelihood, compensation, love and protection for their remaining life through their religious leaders, recognized people or bodies of them.

Therefore the topic for the research was for the developed with the help of intellectual inputs of senior academics of SIBA and MCU.

\section{Significance of the Problem}

There is a necessity to find out, "Why the complainants are not happy who came before the Presidential Commission to investigate in to Complaints regarding their loved ones who went missing in Northern and Eastern Provinces, during the war?

The objective of the research is the prevailing task is task is highly researchable and Sri Lanka need to find out proper reconditions for the grass root level issues. The data collected are primary and the researcher is presently working as a member of the team appointed by the Government of Sri Lanka in the process of investigations. Therefore the researcher selected the topic for his PhD thesis in the style of "Buddhist Approach to the Psycho-social Issues Relating to the Families of Missing Persons in the Civil War in Sri Lanka (from 1983 . 2009)"

\section{Objectives of the Research}

Researcher is appointed for the duties of Presidential Commission to Investigate into Complaints Regarding Missing Persons (PCICMP) which was established on to investigate prevailing Psycho-social Issues in North \& East provinces Sri Lanka, in relation to families of missing persons. Therefore the researcher is fully aware on the specific actions, activities in order to answer research equations, identified.

As mentioned in the above paragraph, researcher wishes to analyze the primary and secondary data in order to find out the magnitude of the humans suffering due to the loss of their loved one/s.

As same as in the above paragraph, researcher has the access to find out the whereabouts of the missing person though military records, records of the Prisoners, detainees, and establishing the interconnectivity with the ongoing patterns of the civilian life through the complains received at the Departments such as Police, Health which can be assertion the mental agony of the families of missing person.

By analyzing the primary and secondary data researcher try to find out the Recommendations and Conclusions for remedial actions to be taken in terms of Justice, Accountability, Reconciliation, Compensation, Avoid future occurrences.

\section{Statement of Problems desired to know}

Primarily, researcher attempts to know the prevailing Psycho-social Issues in North \& East provinces Sri Lanka, in relation to families of missing persons.

Secondarily, researcher attempts to know the magnitude of the humans suffering due to the loss of their loved one/s. 
Thirdly, researcher attempts to know the whereabouts of the missing person by knowing the real facts and the interconnectivity in reducing the severe mental agony by offering the last respects though religious activities by the families of missing person.

Finally researcher attempts to know remedial actions to be taken in terms of Justice, Accountability, Reconciliation, Compensation, Avoid future occurrences, Recommendation and Conclusion at the end of the research.

\section{Scope of Sources of Data \\ Primary data}

Primary data received at the investigations conducted by the Presidential Commission to Investigate into Complaints Regarding Missing Persons (PCICMP) in all districts in North \& East in Sri Lanka.

\section{Secondary data}

Secondary data already available in Sri Lankan Government such as population in geographical area wise, House holders' data collected and preserved by the Police ordinance, Section $76^{[1]}$ in the country, etc.

\section{Scope of Content}

Only North \& East in island, in between year 1983 . 2009 with reference to the Civil War in Sri Lanka.

\section{Research Hypotheses \\ Proposed Hypothesis.}

The Buddhist Approach can addresses the Psycho-social Issues Relating to the Families of Missing Persons in the Civil War in Sri Lanka (from 1983 - 2009)

\section{Proposed Null-Hypothesis;}

The Buddhist Approach cannot address the Psycho-social Issues Relating to the Families of Missing Persons in the Civil War in Sri Lanka (from 1983 - 2009)

\section{Definition of the Terms Used in the Research}

Researcher wish to submit the definitions of the above mentioned terms, as follows.

\section{"Buddhist Approach"}

Most of the belief among the humans is illusory. There are thousands on examples to prove that and what we observe are not the reality. Bodhisatta realized this and enlightened to help others. The true fact is most of the living beings are not awakening.

The concept of illusory creates opportunities for people inviting to be awakening. Before the birth, after birth to the death, after death, may be billions of instances and challenges are well explained in Buddhism to know the reality of the world and the best approach to be followed and we define this procedure and Buddhist approach in knowing the reality.

\section{"Psycho-social Issues"}

Psychology deals with the scientific study of the human mind and its functions, especially those affecting behavior in a given context. The term social connects within characteristic of living individuals or animals or plants. It always refers to the interaction of organisms with other organisms and their collective existence at the same time. Issues are important topics or problems for debates or discussions. The psychosocial approach defines on how individuals in 
the context of the combined behavior of someone with the surrounding in a social environment in terms of physical and mental wellness and their ability to function.

\section{"Missing Person"}

A missing person is a person who has disappeared based on whatever the reason and whose status as alive or dead cannot be confirmed as his or her location and fate are not known, yet.

\section{"Families of Missing Persons"}

Idea behind this term is they need to know about, what happened to his/her relative? Answering this question has become a top priority in the world. Living with uncertainty, creates severe mental agony on the families of missing persons.

\section{"War"}

War is a military or violent conflict between two societies. It is generally characterized by extreme collective violent behavior, action or process of causing so much damage to something that it may no longer exists or cannot be repaired and high levels of damage in terms of death.

\section{“Civil War"}

A civil war is a war or conflict between groups within the same country.

\section{Review of Related Literature and Research Works}

Karen Shalev Greene and Llian Alys have published a book on Missing Persons: A handbook of research, 272 pages, by the publisher, Routledge on October 19, 2016. The book is reviewed by;

Jenny Edkins, Aberystwyth University, UK says an indispensable resource for all concerned with missing children and adults, bringing together in one volume contributions from recognized experts in all aspects of missing people. From the moment someone goes missing, through processes of identification, to what happens when a missing person returns, it provides rich reviews of research data and analysis, and detailed discussions of practice and procedure. All those working with missing persons will welcome this volume. This book illustrates processes of identification, research data and analysis of a missing person ${ }^{1}$

The report of the Lessons Learnt and Reconciliation Commission LLRC of Sri Lanka was mandated to investigate the relevant facts which was influential mainly on failure during the ceasefire agreement which came to effect May 2010. The commission was focused institutional, administrative and legislative measures which were hindering the peace process as a result National Unity was established as expected. Hence the reconciliation was affected and after 18 month Inquiry period the commission submitted their report to the President on 15 November 2011. The general public was made aware on the contents of the report on 16 December 2011, after being tabled in the parliament adhering to the rules and regulations.

It is noted that the Sri Lankan military deliberately target the general public civilian crowd but the rebel group Liberation Tigers of Tamil Eelam (LTTE) repeatedly violated international humanitarian law where evidence where shown and proved. Military was

[1] Karen Shalev Greene. "Missing persons a handbook of research" (2017): 22 01 2018, http://www.worldcat.org/title/missing-persons-a-handbook-of-research/oclc/960976642. 
ordered in order to facilitate the civilians with the highest priority Tamil Tigers had had shown no respect for human life in number of occasions as well. The commission admitted the fact that civillian also has been killed during the operation in accidentally". The commission admitted that civilians had been killed by the Sri Lankan military, albeit accidentally. The Tamil tigers have used civilians as a human shield shield at the front end of the war for the protection. The military as shown zero civilian casualties in some of the humanitarian operations where civilians have helped military in order to get rid of this menace. Because of the domination by the Tamil tigers most of the civilians were innocent and helpless in carrying out there civilian life. Most of the time they are young children as forcely taken out from the houses by stating that they have to sacrifice there life for a concept called Tamil Eelam which was a concept back by the religious motivations. The commission has received eyewitness evidence on the above facts why some of them were ready to go with further investigations while the others were in life including the loved ones. Therefore they do not want to proceed further more because of the inability in doing so and just recorded the complaints as a responsible commission go in action the connected issue represented by the government. In order to prosecute the perpetrators most of them were lost their lives during the operations and there was no possibility in order to move forward with the existing legal procedures. Hence the psychosocial effects were developing at a exponential rate even though many stakeholders were in action but they were not empowered with the administrative, institutional and legislative parameters to handle such complex issues. It is observed even though Goverment has facilities in many ways the proper strategies to the real problem where are not addressed due to typical bureaucracy in democratic Governments. Finally the victims at the end were faced many repercussions due to the problems. In the absence of perpetrators ${ }^{[6]}$ the system of Justice also malfunctioned which were again affected to the victims we are the justice shifted for months and years. The commission has acknowledged that the hospitals also affected sometimes been shelled we are Tamil tigers has taken the patients as human shields which resulted considerable number of civilian casualties reported. The civilian complainants have failed in declaring the parties who were responsible in such attacks where the military as stated the exact locations where the shelling ${ }^{[4]}$ were taken place. There is a remarkable fact mentioned by the commission was that Sinhalese and Tamil politicians both were responsible for causing the civil war while the sinhalese politicians failed to offer a solution acceptable to the Tamil people and the Tamil politicians were keeping absolute silence even though they were making speeches and speeches on behalf of Tamil people but no solution, no genuine efforts were developed as well as not practice other than their political career paths,

Another fact mentioned by the commission is international human rights groups operating on huge donor funded projects we are there United Nations experts were engaged. They were community who had the leverage in bringing both parties to a middle level as both parties wanted justice but not loss of human life as a matter of principle. The underneath parameters of the whole exercise was the he's building but promotion of arms and ammunition and creating market for that well aware to these experts then the Sri Lankan military and the officials of the Government and political leaders in the country. There a question while building the peace how cans the arms and ammunitions were marketed by creates in the avenues for conflicts which lead to war. It is noted that International non government organisations also have failed in order to meet the minimum international standards in order to minimise the gap between the disputes among the two parties. In another way some of the international community head challenge the commission which operates as a tool to prevent an independent international investigation other matters concerned. But none of them were able to introduce preventive measures during the war or commencement of the conflicts as they were very powerful with the 
powers and intervention of the activities of United Nations. Consequence of Amnesty International, Human Rights Watch and the International Crisis Group refused to appear before the commission but they have not properly documented the reasons for their absence while keep on making allegations for Sri Lankan forces for their method of conduct in war related operations.

The report of the commission has played the vital role within the international community where eight high caliber members comprising, where Retired Honorable Attorney General, one of the former Professor of Criminal Justice, Retired Secretary to the Treasury, Retired Secretary for Ministry of Foreign Affairs, Retired Deputy Legal Draftsman \& Retired member of the Monetary Board, Retired High Court Judge, Senior Attorney at law and one of the member of the Human Rights Commission and Retired Sri Lankan ambassador to Qatar served as the secretary to the commission. There were 17 key observations \& 35 recommendations were suggested to the Sri Lankan parliament for action. ${ }^{2}$

Report on the Second Mandate Of the Presidential Commission of Inquiry Into Complaints of Abductions and Disappearances, 248 pages, in August 2015, by the The Presidential Commission Investigating Cases of Missing Persons (PCICMP), Chairman Justice Maxwell Paranagama, Commissioners Mrs. Mano Ramanathan, Mrs. Priyanthi Suranjana Vidyaratne, has specifically mentioned how to deal with Missing Persons and their relatives in the pages, 14, $20,30,129,134,136 \& 163$. In this report the Presidential Commission has done the inquiries on a fact finding process and their recommendations to the Sri Lanka Government.

A Brief Guide on the Legislation to Establish an Office on Missing Persons, by the Centre for Policy Alternatives Sri Lanka, on July 2016, says "Sri Lanka has a significant caseload of enforced and involuntary disappearances spanning decades. In response to the continuing problem involving thousands of missing, successive governments established official investigations and inquiries including several Commissions of Inquiry (CoIs). Despite a string of CoIs, many Sri Lankan's continue their search for truth and justice for past abuses. In 2015, the United Nations Human Rights Council adopted the consensus Resolution tilted 'Promoting Reconciliation, Accountability and Human Rights in Sri Lanka' which provided a framework for transitional justice in Sri Lanka, including the establishment of four specific mechanisms. The Office on Missing Persons (OMP) is to be the first."

In addition to that they work on the Definition of a Missing Person (Clause 27 of the act), Broad mandate of the establishment of the office (Clause 10 of the act), Powers of the OMP (Clause 11 $\& 12$ of the act), Investigative powers (Clause 12 of the act), General Powers (Clause11 of the act), Functions and Duties of the OMP (Clause 13 of the act), Establishment of Office on Missing Persons (Clause 4 of the act), Secretariat (Clause 16 of the act), Tracing Unit (Clause 17 of the act), The Victim \& Witness Protection Division (Clause 18 of the act). Finance (Clause 19of the act) and An Offense of Contempt (Clause 24 of the act).

\footnotetext{
2 Lakshman Wickramasinghe. “The Lessons Learnt and Reconciliation Commission” (2017) : 22 01 2018, http://www.mfa.gov.lk/index.php/en/media/news-archive/3146-the-lessons-learnt-and-reconciliationcommission-llrc-concludes-its-work-the-final-report-will-be-handed-over-to-the-president-on-20-november.
} 
By this report, Establishment of an Office for Missing Persons, in an another dimension in the process of legal frame work are done based on the inquiries on a fact finding perspective together with investigations are carry foreword, after terminating the mandate of Presidential Commission Investigating Cases of Missing Persons (PCICMP).

"Buddhism, Conflict and Violence in Modern Sri Lanka, by venerable Mahinda Deegalle, published 2006, have opened the avenues of new era. He speaks about the "Theravāda Buddhist tradition which could be effectively used in seeking a viable solution to the problem through reconciliation and transformation of violent elements that endanger peace in Sri Lanka"' (https://www.scribd.com/document/202039080/1-Mahinda-Deegalle-BuddhismConflict-and-Violence-in-Modern-Sri-Lanka)

The war has caused serious economic, political, social and moral damage to this primarily Theravāda Buddhist society, which is proud of its liberal cultural heritage and tolerant values cultivated on the basis of Buddhist teachings incorporating non Buddhists and non Sinhalese into its cultural and religious cultures. In his book he discuss how Theravāda Buddhist tradition could help in reconciliation and transformation of violent elements those are directly proportional on peace.

One of the the award winner of Magsaysay 2017, Mrs Gethsie Shanmugam's publication on "healing the wounds of war" has been reported by daily mirror as follows. "Gethsie Shanmugam, an 82-year-old Sri Lankan teacher who counseled war widows and orphans to overcome their nightmares are among the six winners of this year's Ramon Magsaysay Awards, the Hindu reported on 27th July 2017. "Ms. Shanmugam and the other five recipients had been named on Thursday and the awards are to be presented to them in Manila on August 31. The Ramon Magsaysay Award Foundation said Ms. Shanmugam, a teacher and psychological counselor, won for braving bombings and threats of arrests in conflict zones to counsel war widows, orphans and children traumatized by three decades of brutal civil war. rappler.com published about her on September 012017 "War teaches 'each of us is a tool for the healing of ourselves' - Magsaysay Awardee Gethsie Shanmugam who has given psychosocial support to victims of war in Eastern Sri Lanka says 'all change starts with a person"' "Vice President of the Philippines Maria Leonor Robredo, trustees of the Ramon Magsaysay Award Foundation, distinguished guests, members of the Magsaysay family, fellow awardees, ladies and gentlemen. The Ramon Magsaysay Award affirms the spirit of humanity that endures even under the most difficult of circumstances. My work with children and adults living with war, disaster, and other hardships has shown me that even in the context of terrible violence, loss and suffering, there is always the possibility of growth, caring, and hope. Life cannot only continue despite pain and hardships, but can take on new meaning and purpose. Working in war-affected Eastern Sri Lanka in the mid-1990s, I saw how, with encouragement and assistance, children on the small tidal island of Nasivantheevu found the courage to negotiate with the warring parties to allow safe passage for the bus that took them to school, enabling access to an education that would transform their lives. I met a soldier who had lost both his legs in combat, who had thrice considered suicide, and could hardly bear to sit with a member of another ethnic group. I witnessed how, through personal contact, this young man was able to set aside his anger to care for an older woman from a community he deeply mistrusted. Working with widows suddenly thrust into new roles in a society that stigmatized them, I saw how women's determination and hard work enabled them to overcome challenges to secure a life for themselves and their children. Whether working with children or adults, with individuals or groups, my 4 decades of experience has taught 
me that healing and transformation always starts with the person. For people who are in deep pain to begin to heal, it is essential for them to gain self-awareness and acceptance, which in turn shapes their capacity for healthy relationships with others or even towards themselves. This kind of personal growth is often something people overwhelmed by suffering find difficult to do for themselves, but with support and loving care from another human being, like the beautiful lotus that emerges from the mud; these people can be helped to bloom despite the pain they have experienced. As individuals, we often feel that we can't do big things. But we can do small things. All change starts with a person. When one person becomes brighter and relates to others with genuine love, then small groups of individuals can form around them, creating small ripples of change in the world. I believe that each of us is a tool for the healing of ourselves, for the healing of others and for the healing of the societies we live in. No matter who or where we are, we can play a role in making the world a kinder and better place. This is the message that I would like to share with you all. Thank you. Rappler.com" Shanmugam, a counselor and teacher, trained hundreds of psychosocial practitioners and thousands of teachers, building the capacity of Sri Lanka's psychosocial sector. She is recognized for "her compassion and courage in working under extreme conditions to rebuild war scarred lives."

\section{SUMMARY OF LITERATURE REVIEW}

The 1st book taken on the literature review illustrates the processes of identification, research data and analysis of a missing person while the 2nd report has recommended 17 key observations \& 35 recommendations on the missing persons issues to be implemented by the office of cabinet of Ministers, in Sri Lankan parliament, and the 3rd report is a fact finding process and their recommendations to the Sri Lankan Government and by the 4th report it illustrates the necessity of Establishment of an Office for Missing Persons, on an another dimension in the process of legal framework and after terminating the mandate of Presidential Commission Investigating Cases of Missing Persons (PCICMP) and the 5th book has illustrated how Theravāda Buddhist tradition could help in reconciliation and transformation of violent elements those are directly proportional on peace.

After perusing all the above five (5) books and reports it is found all of them discussed the surface level issues, facts and figures directly connected to the missing persons issues and the existing problems faced, avoiding further occurrences, and recommendations to the Sri Lanka Government.

Researcher attempts to go beyond that level aiming at a logical conclusion based on the qualitative \& quantitate data \& information, finally aimed at "Buddhist Approach to the Psychosocial Issues Relating to the Families of Missing Persons in the Civil War in Sri Lanka (from 1983 - 2009)", opening all possible avenues for a next research.

\section{CONCEPTUAL FRAMEWORK}

The conceptual framework of my research covers on my skills, competencies and specialization of few subject domains such as Information Technology, Government Administration, and Law \& Order by active participation in terminating of Sri Lankan Civil War on holding one of the key responsible positions at the Ministry of Defence.

3 Shanmugam Gethsie. "Rebuilding lives from the psychosocial wounds of war and violence ", (2017) : 22012018 , http://rmaward.asia/awardees/shanmugam-gethsie/. 
At the proposal stage, I have submitted five (5) main references on literature review after critical observation and examination of liable published books and reports, at present.

Phenomenon of the civil war assumed because of rising in active, violence against with an established government or a bureaucratic ruler where certain variables are applicable and in force. In academic researches these variables are tested for the interconnectivity. The variables in my research are clearly identified in detail and no room left for confusion or any doubt at the final recommendations. In the methodology of the research these variables are taken at a higher priority in significant findings. I am hoping to build the conceptual framework while considering the interconnectivity of the variables based on the identified scientific articles read by me in addition to the logical facts behind the problem statement used for my research.

The knowledge gap identified in between my research and other researchers which are already published are taken in to serious consideration in order to answer the research question which has not been explained yet.

Whole range of qualitative \& quantitative analysis of observations are to be considered with the interconnectivity of the variables, identified in order to check the influence to the final conclusions Vs the effects of the identified variables. Using a statistical model in identifying the available quantitative data, which are primary, is also an another attempt of me in order to develop possible relationships, while testing them for the certainty and uncertainty with final conclusions.

\section{RESEARCH METHODOLOGY}

Mix of Qualitative and Quantitative data \& information

Researcher attempts to do a comprehensive focus on using mixed method on Quantitative and Qualitative Data Collection and Analysis to integrate Psycho-social Issues Relating to the Families of Missing Persons in the Civil War in Sri Lanka (from 1983 - 2009). By the term "mixed methods" it refers to an establishment of prominent methodology of systematic integration by mixing of quantitative and qualitative data in the research. Final conclusion of this methodology is to be framed by integrating synergistic utilization of data than doing quantitative and qualitative data in isolation.

The research design was primarily developed on following matrix with the aim of collecting primary data and information too be gathered at the open public sittings of the PRESIDENTIAL COMMISSION TO INVESTIGATE INTO COMPLAINTS REGARDING MISSING PERSONS in Sri Lanka. Primary data and information are received in a form of a complaint regarding any Person went missing during war time between June 1990 and May 2009, in Northern or Eastern Provinces. The Presidential commission ${ }^{4}$ of inquiry was appointed by extraordinary gazette no. 1823/425 dated 15th August 2013, under section 2 of the Commission of Inquiry

\footnotetext{
4 Tharushan Fernando, "Around 12,000 complaints left to inquire and investigate": PCICMP Chairman, (2016): 0201 2017, http://newsfirst.lk/english/2016/02/around-12000-complaints-left-to-inquire-and-investigatepcicmp-chairman/128202.

${ }^{5}$ LALITH WEERATUNGA, Secretary to the President, "The Gazette of the Democratic Socialist Republic of Sri Lanka EXTRAORDINARY, Proclamations \& c., by the President, 1823/42" (2013): 02 01 2017, http://www.satp.org/satporgtp/countries/shrilanka/document/papers/PCI.pdf.
} 
Act \# $2^{6}$. Again the time duration for the investigations was amended as 1st January 1983 to May 2009 by the Extraordinary Gazette No.1855/197 dated 25032004.

General information of the missing person

Relatives of missing person

Guiding the families

Accompanying families during the recovery and identification of human remains

Dealing with stress at the consultation.

The following research method was used to optimize the level of input data at the grass root level extracted from the "Information Provider" of the missing person.

Semi-structured interviews: Areas of discussion were predetermined, but the subjects were permitted to approach these in their own way of interpretation and typical interview lasted around 15 - 20 minutes.

Focus groups discussions: A group interviews, with each participant given the chance to express himself or herself, but with the additional dynamic inter group discussion were carried out with community based organizations, NGOs, INGOs.

Participant observation: Additional tools for surveying were carried out based on secondary data already collected with the Government Organizations since it enabled the verbal data gathered in the interviews and the focus group discussions to be confirmed or prove. Participant observation makes it possible to confirm much of the data about economic conditions, relations within community and family, and other elements of social interaction. During interviews, in focus groups and throughout field visits field notes were taken as observations of participants and their environment.

Population considered in this research is from the list of COMPLAINTS RECEIVED. That is 16,179 from Civilians and approximately 5,000 from Security Forces, as at 0904 2015. As a sample it is considered all the participants who gave evidence before the commission which is amounting to 5000 cases covering all the (Grama Niladari) divisions in the island.

There are Eleven (11) type of information are received at the time of recording a complain.

I. Full name of the information provider

II. Information provider's postal address

III. Information provider's NIC number

IV. Relationship to the Information provider by the Person who went missing

V. NIC Number of the Missing Person

VI. Date of Disappearance of the missing person

VII. Nature of Disappearance

VIII. Place of Disappearance

IX. Any information on who was responsible on the Disappearance

$\mathrm{X}$. The places or authorities reported on the same complaint

\footnotetext{
${ }^{6}$ Honorable Attorney General Sri Lanka, "Special Presidential Commissions of Inquiry, Chapter 9, Law No. 7" (1978): 0301 2017, http://www.commonlii.org/lk/legis/consol_act/spcoi9504.pdf.

7 MAHINDA RAJAPAKSA. "The Gazette of the Democratic Socialist Republic of Sri Lanka EXTRAORDINARY", No.1855/19 (2014): 04012017 ,

http://www.satp.org/satporgtp/countries/shrilanka/document/papers/PCICMP.pdf.
} 
XI. Any other information which will be helpful for investigations

\section{Advantages Expected to Obtain from the Research}

The loved ones of a missing person due to whatever the reason behind it live in constant severe mental and physical pain with lot of suffering. The complete loss or absence of hope, often waiting for years for good news creates the agony, worst. No matter how much time has passed, they find it difficult to accept, until reliable proof is provided, that their relative may no longer be alive. The uncertainty in which they have to live is always connected with suffering. It leads to extreme physical and mental fatigue emotionally by not knowing what happened to loved one, may be the parent, spouse or a child and for not being able to give him / her a worthy of respect for the dead body with deep sorrow and passing it to the missing person's grave.

In accordance with the Geneva Conventions and their Additional Protocols, the institutions working on missing persons, have a predetermined permanent mandates on how to assist and protect victims of conflict and other situations of violence. International humanitarian law demand and specify, the right of the families to know the fate of their missing loved ones. The prime responsibility for preventing disappearances and finding the fate of missing persons lies with the government of the said country. They must do everything in their power to provide information on all missing persons to their families.

Entire research is formatted with an Introduction, Literature review, expected Research Methodology, Present Psychosocial Issues relating to the Families of Missing Persons in Sri Lanka. Identification of Problems, cause and effect of the incidents of missing persons families, milestones of the Escalation of development of war conflict, Existing issues and problems related to families of missing persons, what can get from the Buddhist teachings and Conclusion illustrating of how to establish Justice, Accountability of the Government, the process of Reconciliation, the Compensation, establishment of all possible ways \& means in order to avoid future occurrence and Recommendations from the researcher.

\section{CHAPTER V \\ RECOMMENDATIONS ON JUSTICE, ACCOUNTABILITY, RECONCILIATION, COMPENSATION AND SUGGESTED METHODOLOGY IN AVOIDING FUTURE OCCURRENCES IN A GLOBAL PERSPECTIVE}

\section{Conclusions and Suggestions Conclusions}

The supposition and the proposed explanation of the dissertation was made on the basis of limited scattered evidence which were available in North and East provinces in Sri Lanka. Hypothesis and Null-Hypothesis were derived in the paragraphs 1.7.1 and 1.7.2 as follows,

\section{Proposed Hypothesis}

The Buddhist Approach can addresses the Psycho-social Issues Relating to the Families of Missing Persons in the Civil War in Sri Lanka (from 1983 - 2009)

\section{Proposed Null-Hypothesis}

The Buddhist Approach cannot address the Psycho-social Issues Relating to the Families of Missing Persons in the Civil War in Sri Lanka (from 1983 - 2009)

In chapter three (3) analyses of Primary Data, Secondary Sources, Discussion and Solutions found by the researcher based on a mixture of Quantitative \& Qualitative Research was presented. 
Number of Complaints Invited Vs Number of Complaints Inquired Vs Number of new complaints registered were and eye opening to PCICMP and the Sri Lankan Government after ending the Civil war in the country. Time gap was from the day war was ended on 18052009 until PCICMP was established on 15 August 2013 was almost 5 years. During such time all the issues were in full scale at the grass root level attended by the respective stakeholders at their level best. After the official assignment granted to the researcher by the Ministry of Defence he was able to initiate this valuable research on a legitimate platforms supported by academic research standards. The primary data set was exclusively collected and properly uploaded on relational databases for the research purposes as well as in order to fulfill administrative perspectives in locally and internationally. Total number of complaints Invited were 9556, number of complaints Inquired at the public sittings conducted covering North and Eastprovinces were 6425 and the number of new companies registered at all the sessions were 7422.

These values were so important becaise after five years of ending the war there were 7422 complaints which were not known by the stakeholders. That means the magnitude of the pain or the tears on the ground we are not known. It is directly proportional to the psychosocial issues of the target community.

PCICMP came to an end in July 2015 and received over 23,586 complaints inclusive of approximately 5,000 complaints from the relatives of missing Security Forces personnel. Commission investigated into 6425 inquiries of missing persons who were affected by the war during the period of June 10, 1990 and May 19, 2009. Researcher established 18891 complaints during the period of mandate of PCICMP. The difference was 4695 in between the total complaints received 23,586 and the database prepared based on the official complaints received at the public hearing which was 18891. PCICMP conducted several approaches in order to find out the rationale behind the difference and found most of them were belongs to members of security forces and Police while some of them were on duplications and replicated where the followers of missing persons have reported the same complain to the local and international stakeholders for relief.

By analyzing of primary and secondary data sets on a mixture of quantitative \& qualitative research produced number of data tables and graphs illustrating most of the unknown perspectives of the problem. Attributes of the data has shown integrated functionalities of the root causes of psychosocial impacts at the household level which has been propagated at the society, village levels and developed upto local and international level creative many repercussions at a exponential trend.

In Chapter four (4) researcher illustrated the theories and the principles taught by the Buddha and the connectivity of early Buddhist attitude towards conflict resolution. Number of Sutta were extracted and taken in to study on how was the principles were affecting before a conflict where it could be avoided at the early stages. Sri Lanka has failed in doing so before commencement of the war as well as during the peacekeeping missions in order to minimise or eradicate the devastation even though the majority of Sri Lankans are Buddhists. Researcher has discussed these concepts in detail in this chapter.

In Chapter five (5) researchers developed the recommendations on Justice, accountability, reconciliation, compensation and suggested methodology in avoiding future occurrences in a global perspective. The entire chapter was composed by amalgamating the findings of the data analysis of primary and secondary sources together with the facts and figures of the existing 
ongoing wars in the world, magnitude of the efforts done by the United Nations on sixteen (16) peacekeeping missions around the world at a cost on billions of dollars, tears and the sufferings of the victims of the wars.

By considering the above facts mentioned the proposed hypothesis and proposed NullHypothesis where reexamined and tested. Established of the hypothesis of "The Buddhist Approach can addresses the Psycho-social Issues Relating to the Families of Missing Persons in the Civil War in Sri Lanka (from 1983 - 2009)" was TRUE while null-hypothesis which is "The Buddhist Approach cannot address the Psycho-social Issues Relating to the Families of Missing Persons in the Civil War in Sri Lanka (from 1983 - 2009)" was UNTRUE, NULL and VOID.

\section{Suggestions}

By considering the above conclusions and due to the limitations of the research the followings are documented as a starting point for further investigation and research.

Suggested to conduct further research on the entire population of the data set which has a direct impact to the followers of the missing persons family as they are on continuous tragedy of psychosocial issues which are in full scale during their present life, irrespective of the ethnicity, race, level of economy, etc, etc

Other than the facts mentioned above by the researcher specially on the areas on justice, accountability, reconciliation, compensation and all possible methodologies in avoiding future occurrences are to be expedited with immediate effect.

\section{Members of the Missing Persons Commission}

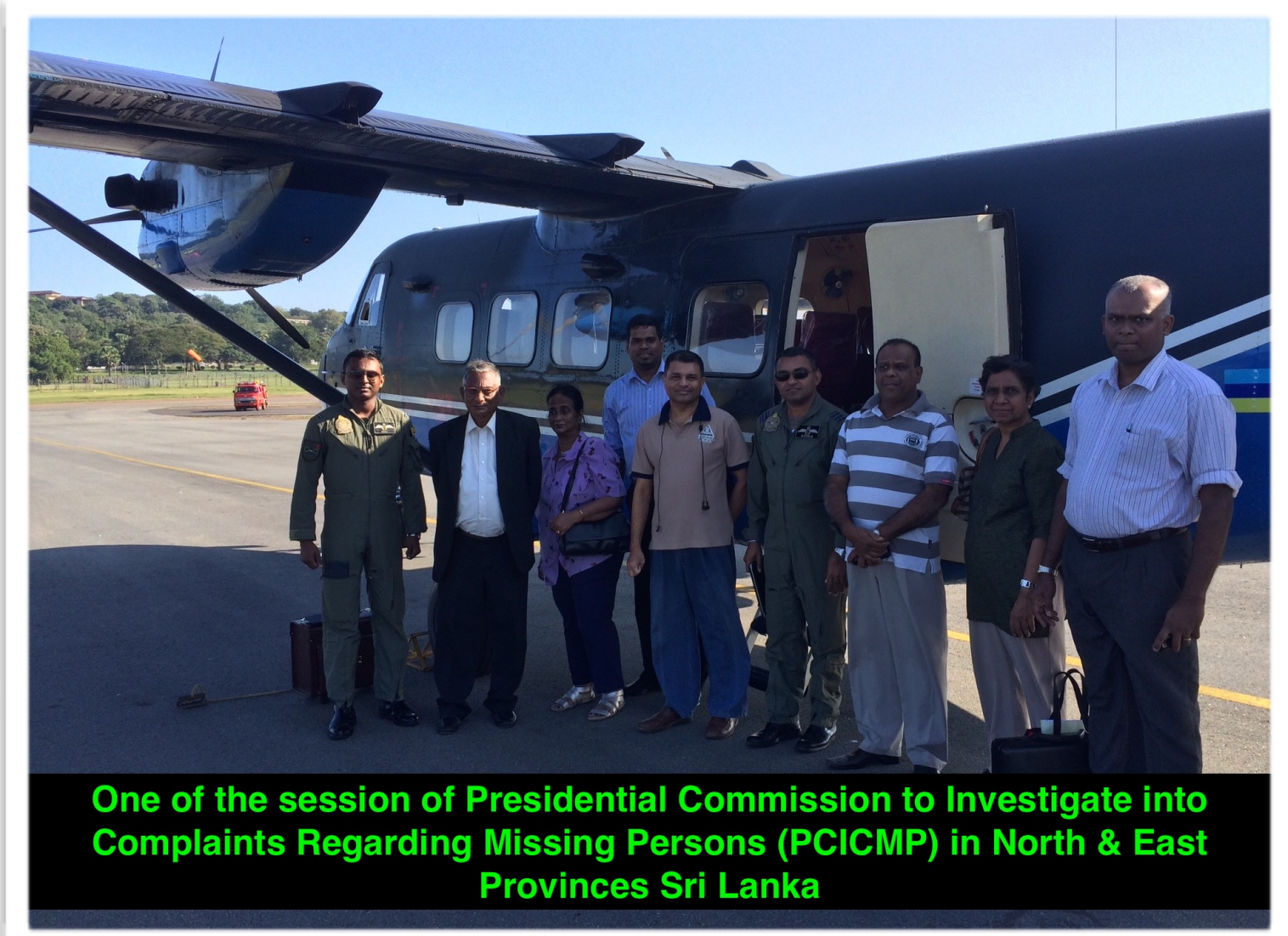


Mudalige, J., Vuḍḍhikaro, P. S., Sedere, U. M., Edirisinghe, D., Ariyaratne, I., \& Mudalige, M. J. M. (2018). Buddhist Approach To The Psycho-Social Issues Relating To The Families Of Missing Persons In The Civil War In Sri Lanka (FROM 1983 . 2009). Advances in Social Sciences Research Journal, 5(3) 122-139.

\section{One of the hearings conducted by the commission}

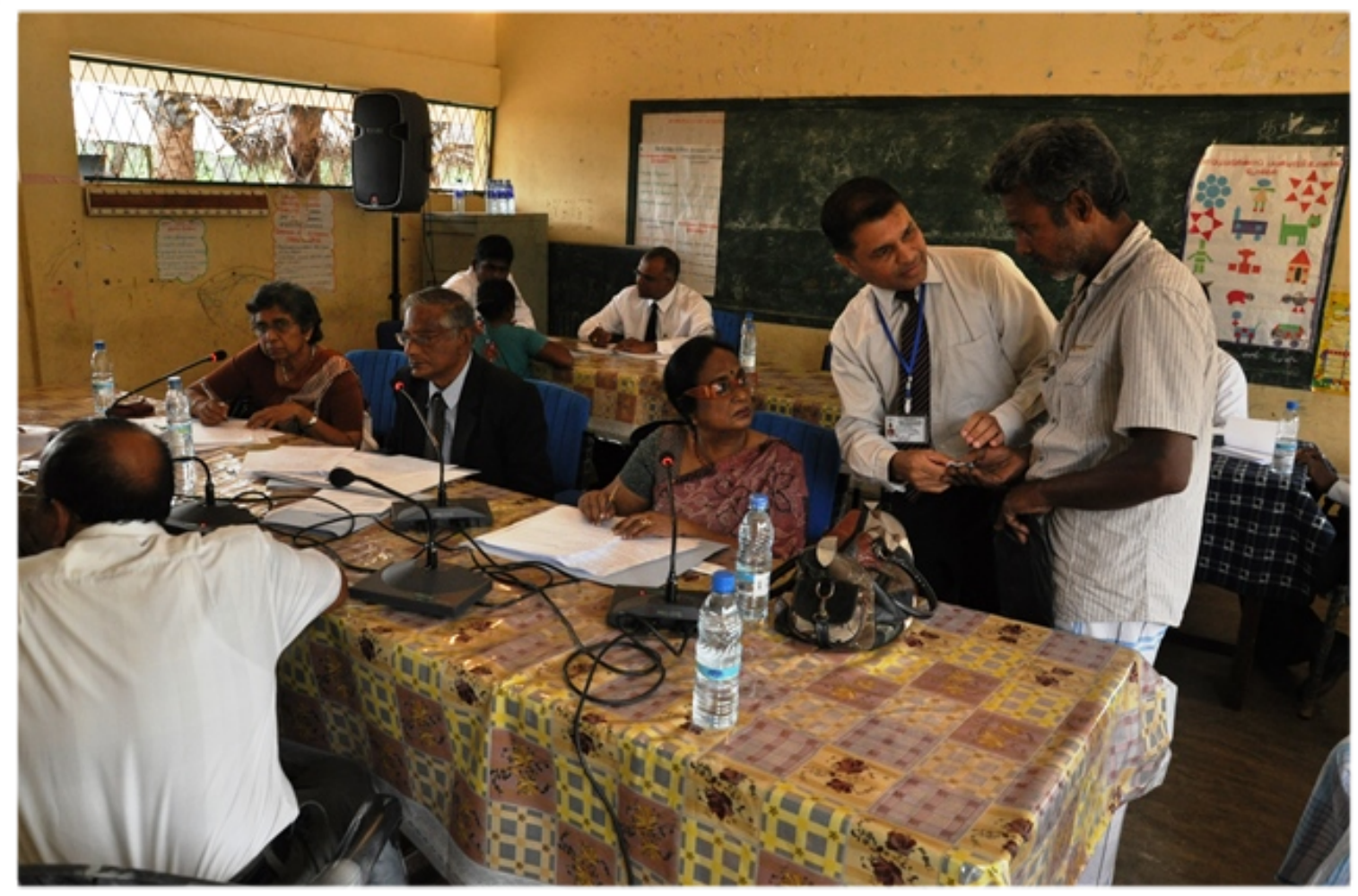

Official duties at Point Pedro in Jaffna District

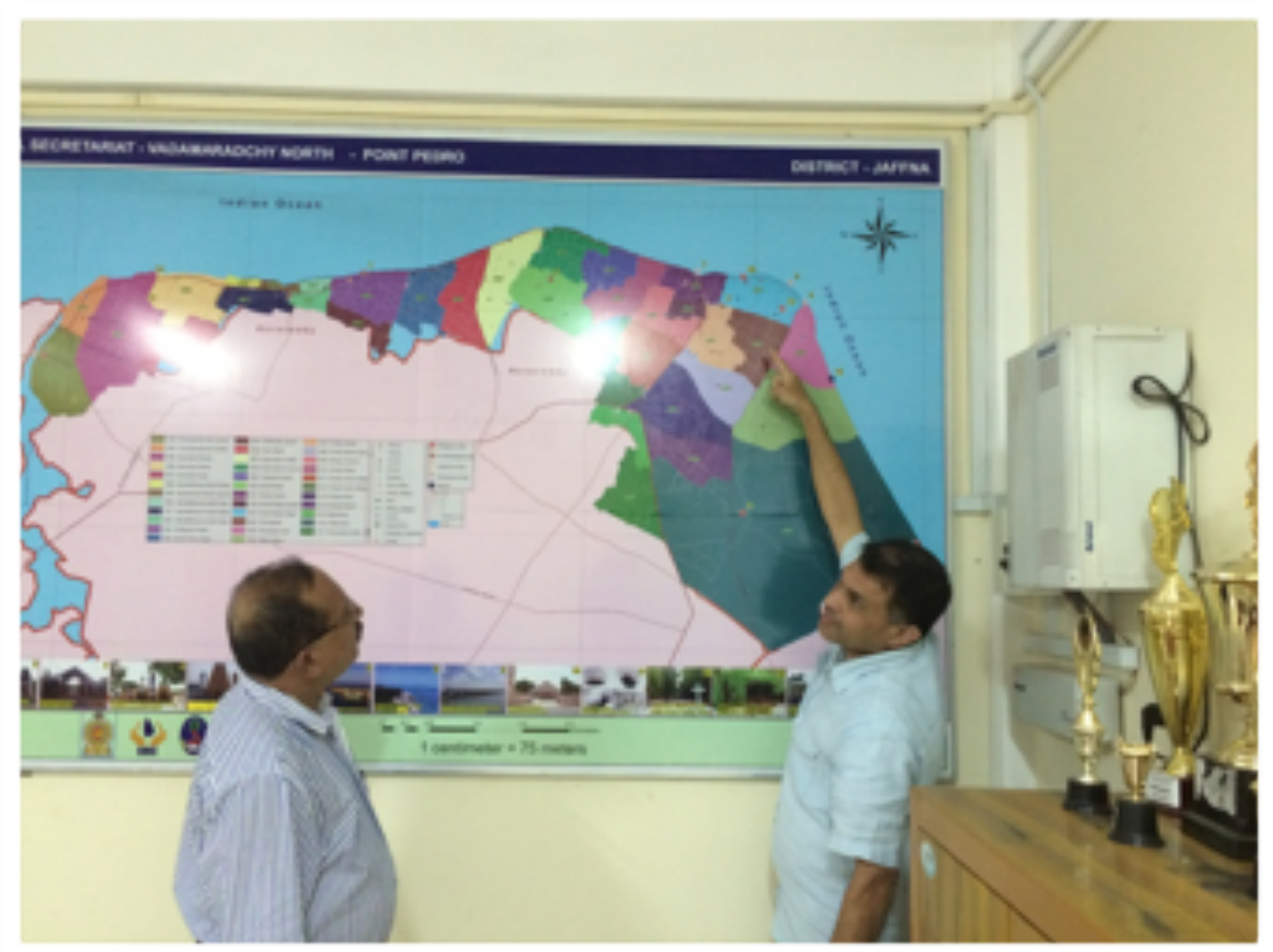


Pilot Kokila Abeywardane of Air Force \& myself while on duty. Missing Persons Commission. North \& East Sri Lanka.

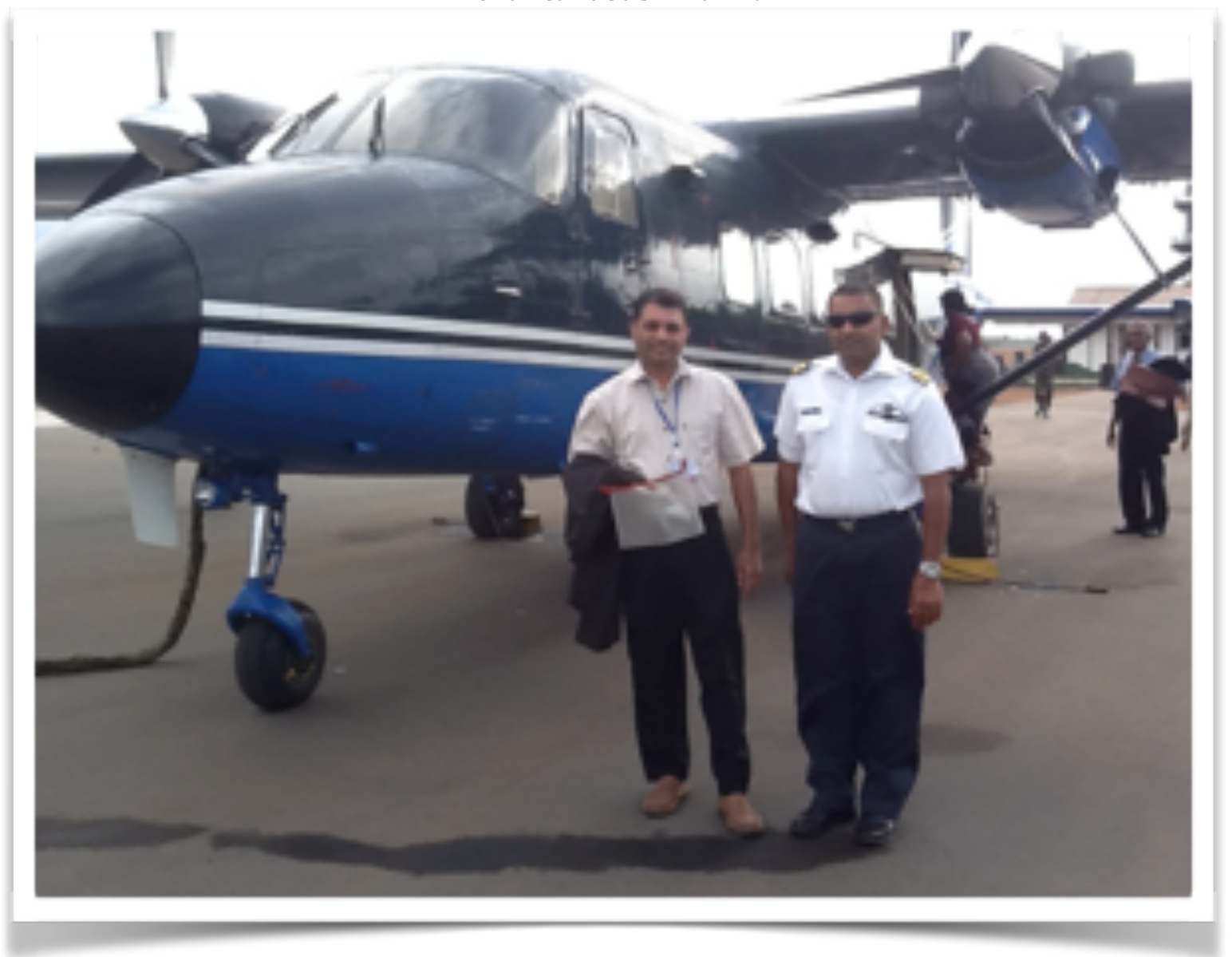

